\title{
True ileal digestibility of amino acids of pea seeds and soyabean products estimated in pigs, rats and in vitro*
}

\author{
E. Święch ${ }^{1}$ and L. Buraczewska \\ The Kielanowski Institute of Animal Physiology and Nutrition, \\ Polish Academy of Sciences \\ 05-110 Jabtonna, Poland
}

(Received 1 July 2004; revised version 22 November 2004; accepted 31 January 2005)

\begin{abstract}
The standardized ileal digestibility/true ileal digestibility (SID/TID) of protein and amino acids (AA) in low- and high-tannin pea seeds and soyabean products (soyabean meal, raw soyabean, extruded soyabean) containing different levels of trypsin inhibitor activity was determined and compared in growing cannulated pigs, in adult rats and using in vitro method. Endogenous losses of protein and AA at the ileal level were estimated in rats after feeding protein-free diet and were found to be similar to tabulated values for pigs. Protein and AA SID was significantly higher in pigs fed with low- than with high-tannin pea. In rats, AA TID was also higher in animals fed low-tannin pea, however, values were significantly different only for few AA. The in vitro AA SID measured in six pea cultivars decreased linearly with increasing tannin contents. Addition of raw soyabeans to a diet significantly decreased protein and AA SID/TID in both animal species, as compared to soyabean meal diet. The in vitro protein and AA SID was not affected by trypsin inhibitor activity. In conclusion, to rank feedstuffs according to their AA digestibility for pigs using alternative methods, the in vitro method is suitable for peas containing different levels of tannins, while rats are sensitive enough to trypsin inhibitor activity to differentiate soyabean feedstuffs.
\end{abstract}

KEY WORDS: pigs, rats, in vitro, ileal digestibility, endogenous losses, amino acids

\section{INTRODUCTION}

The determination of amino acid (AA) digestibility in feedstuffs for pigs is an important point in protein evaluation system. It is usually accepted that the method based on ileal than faecal digestibility measurement should be used (Mosenthin et al., 2000). Protein and AA ileal digestibility may be expressed as apparent (AID) or true (TID), including standardized ileal digestibility (SID). It is agreed that the TID and SID determinations, recognized as comparable, are more correct than AID.

\footnotetext{
* Supported by the State Committee for Scientific Research, Grant No. 6 PO 6E 03020

${ }^{1}$ Corresponding author: e-mail: e.swiech@ifzz.pan.pl
} 
Values of AID are influenced by protein and AA level in the diet whereas TID and SID are not. The difference between AID and TID/SID is related to basal endogenous losses of protein (EPL) and AA (EAAL) (Boisen, 1998). For TID calculations, the AID and basal EAAL are to be determined using the same animals, while SID values are calculated using average literature values for basal EAAL, as recommended by Rademacher et al. (1999) for pigs.

The basal EPL and EAAL are defined as the minimal losses of CP and AA related to the dry matter intake. Basal EPL and basal EAAL, in contrast to their extra losses, are independent of the composition of a feedstuff or of a diet. Presence of fibre and antinutritional factors can cause extra losses of nitrogen compounds (Boisen and Moughan, 1996). The amounts of basal EPL and EAAL at the ileal level may be determined by several methods, e.g., protein-free feeding, regression method, enzyme hydrolysed casein (EHC), etc. (Boisen and Moughan, 1996).

The determination of TID by conventional method on pigs is time-consuming and expensive thus more simple and cheaper methods for routine determination of protein and AA digestibility in feedstuffs and feed mixtures for pigs are seeked for. Among in vitro methods, the multienzymatic method of prediction AA digestibility in feedstuffs and feed mixtures for pigs has been proposed by Boisen and Fernández (1995). The use of rat as a suitable animal model for pigs for estimating the ileal digestibility of protein and AA in feedstuffs was introduced by Skilton et al. (1991). The number of studies relating results of protein and AA digestibility determinations using alternative methods to experiments with pigs is limited.

Pea seeds and soybeans are high protein feedstuffs, but contain also various antinutritional factors, e.g., tannins and trypsin inhibitors. Tannins are known to affect negatively nutrient digestibility. Trypsin inhibitors can cause serious disturbances to physiological processes, including digestion and absorption.

The aim of the study was to assess the validity of in vitro assay and rat assay in evaluating protein value for pigs of two types of high-protein feedstuffs: pea seeds and soyabean products. Protein and AA SID or TID of peas with different tannin contents and of soyabean products with different trypsin inhibitor activity were determined in pigs, rats, and in vitro.

\section{MATERIAL AND METHODS}

\section{Feeds and diets}

Two varieties of white-flowering (Agra, Albatros) and four varieties of colouredflowering pea (Grapis, Selga, Retro, Almara) were analysed (Table 1) and used in the study. For in vivo trials, two diets were prepared, one with the pea var. Agra and one with var. Grapis containing 0.4 and $5.2 \mathrm{~g}$ tannins per $\mathrm{kg} \mathrm{DM}$, respectively. Both diets contained the same amount of crude protein $\left(158 \mathrm{~g} \mathrm{~kg}^{-1}\right)$. 
TABLE 1

Chemical composition ( $\left.\mathrm{g} \mathrm{kg}^{-1} \mathrm{DM}\right)$, content of amino acids (g per $\left.16 \mathrm{~g} \mathrm{~N}\right)$, tannin contents $\left(\mathrm{g} \mathrm{kg}^{-1}\right.$ $\mathrm{DM})$ and trypsin inhibitor activity (TIA) in six cultivars of pea

\begin{tabular}{|c|c|c|c|c|c|c|}
\hline \multirow{2}{*}{$\begin{array}{l}\text { Pea } \\
\text { cv. }\end{array}$} & \multicolumn{2}{|c|}{ Low-tannin } & \multicolumn{4}{|c|}{ High-tannin } \\
\hline & Albatros & Agra & Grapis & Selga & Retro & Almara \\
\hline Crude protein & 236.9 & 198.1 & 244.5 & 239.9 & 225.0 & 230.3 \\
\hline Ether extract & 9.20 & 12.3 & 11.0 & 13.1 & 16.6 & 12.5 \\
\hline Ash & 32.2 & 34.1 & 32.6 & 34.3 & 32.1 & 29.9 \\
\hline Crude fibre & 65.8 & 71.4 & 68.3 & 66.7 & 67.9 & 73.5 \\
\hline $\mathrm{ADF}$ & 90.3 & 96.3 & 104.7 & 87.0 & 90.7 & 97.1 \\
\hline NDF & 152.2 & 159.3 & 146.9 & 116.9 & 117.7 & 138.7 \\
\hline \multicolumn{7}{|l|}{ Amino acids } \\
\hline lysine & 7.40 & 7.62 & 6.77 & 7.21 & 7.16 & 7.51 \\
\hline methionine & 0.92 & 1.08 & 0.94 & 0.87 & 0.97 & 1.03 \\
\hline cystine & 1.27 & 1.66 & 1.42 & 1.41 & 1.56 & 1.56 \\
\hline threonine & 3.95 & 3.97 & 3.55 & 3.63 & 3.68 & 3.83 \\
\hline tryptophan & 0.95 & 0.84 & 0.82 & 0.92 & 0.95 & 0.98 \\
\hline isoleucine & 4.17 & 4.16 & 3.67 & 4.08 & 4.07 & 4.31 \\
\hline Tannins & 0.20 & 0.40 & 5.20 & 8.20 & 9.50 & 11.5 \\
\hline TIA $^{1}$ & 1.92 & 3.40 & 3.05 & 2.44 & 3.56 & 2.49 \\
\hline
\end{tabular}

${ }^{1}$ TIA - trypsin inhibitor activity expressed as mg pure trypsin inhibited per g DM

Also, three soyabean products: soyabean meal (SBM), raw soyabean (RSB) and extruded soyabean (ESB) were analysed (Table 2) and used in the trials. Three diets were prepared for pigs and rats: one diet with SBM and two diets with

TABLE 2

Chemical composition $\left(\mathrm{g} \mathrm{kg}^{-1} \mathrm{DM}\right)$, content of amino acids (g per $16 \mathrm{~g} \mathrm{~N}$ ) and trypsin inhibitor activity (TIA) in soyabean products

\begin{tabular}{lccc}
\hline Indices & $\begin{array}{c}\text { Soyabean meal } \\
(\text { SBM })\end{array}$ & $\begin{array}{c}\text { Raw soyabean } \\
(\mathrm{RSB})\end{array}$ & $\begin{array}{c}\text { Extruded soyabean } \\
(\text { ESB) }\end{array}$ \\
\hline Crude protein & 518.9 & 386.9 & 361.5 \\
Ether extract & 24.8 & 220 & 240 \\
Ash & 77.7 & 51.3 & 50.6 \\
Crude fibre & 39.4 & 88.6 & 47.2 \\
ADF & 69.0 & 113.1 & 70.7 \\
NDF & 131.5 & 159.9 & 101.8 \\
Amino acids & & & \\
$\quad$ lysine & 6.29 & 6.32 & 6.33 \\
$\quad$ methionine & 1.40 & 1.44 & 1.46 \\
$\quad$ cystine & 1.53 & 1.60 & 1.59 \\
threonine & 4.07 & 4.22 & 4.06 \\
tryptophan & 1.35 & 1.38 & 1.31 \\
isoleucine & 4.62 & 4.63 & 4.58 \\
TIA & & & 15.5 \\
\hline
\end{tabular}

\footnotetext{
${ }^{1}$ expressed in mg trypsin inhibited per g DM
} 
mixtures of SBM and RSB or ESB. The diet with ESB was not used in the pig experiment. All soyabean diets contained similar amounts of crude protein $\left(172-174 \mathrm{~g} \mathrm{~kg}^{-1}\right)$. The composition of the diets is given in Table 3. Calculated metabolizable energy was about $13.4 \mathrm{MJ} \mathrm{kg}^{-1}$.

TABLE 3

Composition of diets, $\mathrm{g} \mathrm{kg}^{-1}$, as-fed

\begin{tabular}{|c|c|c|c|c|c|c|}
\hline \multirow{3}{*}{ Indices } & \multicolumn{6}{|c|}{ Diets } \\
\hline & \multicolumn{2}{|c|}{ pea } & \multicolumn{3}{|c|}{ soyabean products } & \multirow{2}{*}{ Cereals } \\
\hline & LTP & HTP & SBM & $\mathrm{SBM}+\mathrm{RSB}$ & $\mathrm{SBM}+\mathrm{ESB}$ & \\
\hline \multicolumn{7}{|l|}{ Ingredients } \\
\hline maize & 125.6 & 125.6 & 192.7 & 192.7 & 192.7 & 258.3 \\
\hline triticale & 347.5 & 347.5 & 533.4 & 533.4 & 533.4 & 714.8 \\
\hline low-tannin pea Agra (LTP) & 500.0 & & & & & \\
\hline high-tannin pea Grapis (HTP) & & 500.0 & & & & \\
\hline soyabean meal $(\mathrm{SBM})$ & & & 235.0 & 150.0 & 150.0 & \\
\hline raw soyabean $(\mathrm{RSB})$ & & & & 100.0 & & \\
\hline extruded soyabean (ESB) & & & & & 100.0 & \\
\hline vit. - min. mixture ${ }^{1}$ & 15.0 & 15.0 & 15.0 & 15.0 & 15.0 & 15.0 \\
\hline $\mathrm{Cr}_{2} \mathrm{O}_{3}$ & 3.0 & 3.0 & 3.0 & 3.0 & 3.0 & 3.0 \\
\hline $\mathrm{NaCl}$ & 0.9 & 0.9 & 0.9 & 0.9 & 0.9 & 0.9 \\
\hline limestone & 8.0 & 8.0 & 5.0 & 5.0 & 5.0 & 8.0 \\
\hline soyabean oil & & & 15.0 & & & \\
\hline \multicolumn{7}{|l|}{ Calculated } \\
\hline crude protein, $\mathrm{g} \mathrm{kg}^{-1}$ & 158 & 158 & 174 & 172 & 172 & 110 \\
\hline $\mathrm{ME}, \mathrm{MJ} \mathrm{kg}^{-1}$ & 13.4 & 13.4 & 13.4 & 13.4 & 13.4 & 13.3 \\
\hline TIA $^{2}$ & 1.45 & 1.33 & 0.79 & 3.42 & 1.95 & n.d. \\
\hline
\end{tabular}

${ }^{1}$ vit-min. mixture (Polfamix T; BASF, Poland) contains in $1 \mathrm{~kg}$ : flavomycyn, $0.5 \mathrm{~g}$; IU: vit. A, 320000 ; vit. $\mathrm{D}_{3}, 80000$; g: vit. E, 0.32; vit. $\mathrm{B}_{2}, 0.16$; folic acid, 0.02 ; nicotinic acid, 0.8; choline chloride, 4; Mn, 3.2; Fe, 0.84; Zn, 1.84; Cu, 0.32; J, 0.2; Co, 0.12; Ca, 280; P, 140; Na, 45; mg: vit. $\mathrm{B}_{12}, 28$, calcium panthothenate, 0.32

${ }^{2}$ TIA - trypsin inhibitor activity expressed as mg pure trypsin inhibited per g DM

Each experimental diet contained maize and triticale in proportion of 1:2.8 and one or two protein feedstuffs. Control diet contained maize and triticale in the same proportion as in the experimental diets. Protein-free diet was prepared for estimation basal EPL and basal EAAL in rats. The diet was composed of $\left(\mathrm{g} \mathrm{kg}^{-1}\right)$ : maize starch, 752; saccharose, 100; cellulose, 50; soya oil, 40; vitamin mixture, 35; mineral mixture, 20, and chromic oxide, 3. Chromic oxide was used as a marker.

Experiments on animals 
The experimental procedures were approved by the ethics committee of the Kielanowski Institute of Animal Physiology and Nutrition (Jabłonna, Poland).

The experiment on pigs was carried out on twelve male castrates (Polish synthetic line 990) within a body weight (BW) from 30 to $70 \mathrm{~kg}$. Following 5 days of adaptation to the cages, the pigs were surgically fitted with a post-valvular T-caecum (PVTC) cannula according to van Leeuwen et al. (1991). After 7 day recovery period, they were housed in individual metabolic cages in a temperature-controlled room (20-22 ${ }^{\circ} \mathrm{C}$ ). Experimental diets were fed according to change-over design; each diet was given to six animals. Pigs were fed twice daily at 08.00 and $20.00 \mathrm{~h}$, diets mixed with water in the ratio 1:1. Pigs were individually fed at 3 times maintenance requirement for metabolizable energy $\left(1.4 \mathrm{MJ} \mathrm{ME} / \mathrm{kg} \mathrm{BW}^{0.75}\right)$. Water was available from drinking nipples. After adaptation of the animals to the diets, the ileal digesta was collected in plastic bags for 3 days, $12 \mathrm{~h}$ per day $(08.00-20.00 \mathrm{~h})$. The bags were connected to the canulas and were changed at least every hour, and their contents were immediately frozen in plastic containers at $-20^{\circ} \mathrm{C}$. After completing the collections, samples were thawed, pooled per animal within each experimental period, freeze-dried and ground $(0.5 \mathrm{~mm})$ before chemical analysis. Contents of nitrogen, AA, and chromic oxide were analysed in freeze-dried ileal digesta. The pigs were slaughtered at the end of the experiment and dissected to observe whether cannulation had caused any intestinal abnormalities.

The experiment on rats was carried out on male rats at $\mathrm{BW}$ about $250 \mathrm{~g}$. The animals were housed individually in metabolic cages at $22 \pm 2^{\circ} \mathrm{C}$ with a 12 -h light/dark cycle. Fresh water was available at all times. Experimental diets $(15 \mathrm{~g})$ were fed once daily, in the morning. On the fourth day of feeding experimental diets, animals were slaughtered $4 \mathrm{~h}$ after the meal and digesta was collected from the distal quarter of the small intestine. Samples from 4-6 animals were pooled and treated as an experimental unit. There were 5 experimental units per diet. The digesta samples were immediately frozen and stored at $-20^{\circ} \mathrm{C}$ and freeze-dried. The stomach contents of each rat were checked to ensure that coprophagy had not occurred.

\section{In vitro assay}

All six pea cultivars and the soyabean products were used for in vitro determination by Boisen and Fernández (1995) method. For this assay, soyabean products were mixed in the same proportions like in the diets and diluted with maize starch to obtain protein contents of about $180 \mathrm{~g}$ per $\mathrm{kg}$. Precaecal digestion was simulated by two consecutive incubations corresponding to digestion in the stomach and in the small intestine: with pepsine at $\mathrm{pH} 2.0$ for $6 \mathrm{~h}$ and with pancreatin at $\mathrm{pH}$ 6.8 for $18 \mathrm{~h}$, at $39^{\circ} \mathrm{C}$. 


\section{Chemical analysis}

Dry matter (DM), nitrogen $(\mathrm{N})$, ether extract, crude fibre were estimated using standard methods (AOAC, 1990). The content of neutral detergent fibre (NDF) and acid detergent fibre (ADF) were determined with Fibertec System M by methods of van Soest and Wine (1967) and van Soest (1973). Chromic oxide was determined according to Kimura and Miller (1957). Amino acid analyses were performed with Beckman 6300 high pressure amino acid analyser using modified procedures described by Buraczewska and Buraczewski (1984). The condensed tannin content was analysed according to Kuhla and Ebmeier (1981). The trypsin inhibitor activity (TIA) was estimated using method of Kakade et al. (1974) modified by Valdebouze et al. (1980) and An et al. (1993).

\section{Calculation}

The protein and AA SID of pea seeds and soyabean products in pigs and the TID in rats were calculated by difference method using digestibility values of the control cereal diet and by correction for basal EPL and basal EAAL at the ileal level. The level of basal EPL and EAAL was estimated for pigs at the average literature value (Rademacher et al., 1999) and determined for rats after feeding a protein-free diet.

In vitro protein and amino acid AID and SID were calculated by correcting for EPL and EAAL using respective equations of Boisen and Fernández (1995) and Boisen (1998).

\section{Statistical analysis}

One-way analysis of variance was carried out on the experimental results using pea cultivar or type of soyabean product as an independent variables for each group of feedstuffs separately. The significance of differences between means was tested with the Ducan-test. All calculations were performed using Statistica 5.5 PL (1997).

\section{RESULTS AND DISCUSSION}

Endogenous protein and amino acid losses at the ileal level in rats

Current protein evaluation systems are based on ileal digestible protein and AA. Values of TID or SID are preferred due to independence of dietary and experimental conditions (Mosenthin et al., 2000). Protein and AA TID and SID coefficients are calculated from AID by correcting them for endogenous losses. In 
this study, EPL and EAAL for pigs were taken from literature (Rademacher et al., 1999) and for rats were assessed after protein-free feeding, as the literature values are widely variable (Donkoh et al., 1995; Hendriks et al., 2002; Rutherfund and Moughan, 2003). Results obtained in this study (Table 4) were higher for few AA than those obtained by others using the same method but similar to values obtained when EHC/ultra filtration method was used (Donkoh et al., 1995; Hendriks et al., 2002) and close to literature values for pigs proposed by Rademacher et al. (1999). Only endogenous loss of tryptophan in rats was higher up to $25 \%$, as compared with average values for pigs.

TABLE 4

Basal endogenous protein and amino acid losses at the ileal level in rats fed protein-free diet

\begin{tabular}{lcc}
\hline \multirow{2}{*}{ Indices } & \multicolumn{2}{c}{ Endogenous losses, $\mathrm{g} \mathrm{kg}^{-1} \mathrm{DM}$ intake } \\
\cline { 2 - 3 } & mean & $\mathrm{SD}$ \\
\hline Protein & 11.48 & 0.320 \\
Lysine (Lys) & 0.400 & 0.057 \\
Methionine (Met) & 0.119 & 0.002 \\
Cystine (Cys) & 0.249 & 0.006 \\
Threonine (Thr) & 0.631 & 0.014 \\
Tryptophan (Trp) & 0.204 & 0.012 \\
Isoleucine (Ile) & 0.425 & 0.014 \\
& & \\
Arginine (Arg) & 0.398 & 0.011 \\
Histidine (His) & 0.215 & 0.009 \\
Leucine (Leu) & 0.565 & 0.031 \\
Phenylalanine (Phe) & 0.325 & 0.012 \\
Valine (Val) & 0.460 & 0.012 \\
Alanine (Ala) & 0.354 & 0.017 \\
Aspartic acid (Asp) & 0.983 & 0.024 \\
Glutamic acid (Glu) & 0.911 & 0.038 \\
Glycine (Gly) & 1.074 & 0.059 \\
Proline (Pro) & 0.499 & 0.017 \\
Serine (Ser) & 0.549 & 0.011 \\
Tyrosine (Tyr) & 0.734 & 0.009 \\
\hline
\end{tabular}

Effect of tannin content on protein and AA digestibility in pea seeds

The chemical composition of the six varieties of pea used in the study (Table 1) is in agreement with literature values (Gdala et al., 1992; Grosjean et al., 2000). Pea varieties Grapis, Selga, Retro, and Almara contained much higher level of tannins than the low-tannin peas Albatros and Agra. Trypsin inhibitor activity was similar in all varieties. Protein content ranged from 198 to $245 \mathrm{~g} \mathrm{~kg}^{-1} \mathrm{DM}$ and amino acid analysis showed a relatively low level of methionine and high content of lysine in the peas. 
Protein and AA SID was significantly higher in pigs fed the diet with the low-tannin pea Agra than with the high-tannin pea Grapis (Table 5). The respective digestibility of tryptophan, methionine, and cystine was lowest and the digestibility of lysine and histidine was highest in both varieties. These results are in accordance with the results obtained by Gdala et al. (1992) and Grosjean et al. (2000). The negative influence of tannins on ileal digestibility of protein and AA in pigs can be explained by formation of complexes between tannins and feed proteins, by decreasing enzyme activity and/or by increasing EPL as an effect of damage of mucosa and increase of mucin secretion.

TABLE 5

True $^{1}$ ileal digestibility of protein and amino acids of two varieties of pea determined on pigs and rats

\begin{tabular}{|c|c|c|c|c|c|c|c|c|}
\hline \multirow{2}{*}{$\begin{array}{l}\text { Animals } \\
\text { Pea cv. }\end{array}$} & \multicolumn{4}{|c|}{ Pigs } & \multicolumn{4}{|c|}{ Rats } \\
\hline & Agra $^{2}$ & Grapis & SEM & $\mathrm{P} \leq$ & Agra & Grapis & SEM & $\mathrm{P} \leq$ \\
\hline Protein & $75.3^{\mathrm{B}}$ & $70.6^{\mathbf{A}}$ & 0.84 & 0.001 & 77.0 & 78.2 & 0.45 & NS \\
\hline Lys & $85.4^{\mathrm{b}}$ & $82.2^{\mathrm{a}}$ & 0.78 & 0.05 & 87.8 & 86.9 & 0.40 & NS \\
\hline Met & $75.5^{\mathrm{B}}$ & $63.3^{\mathrm{A}}$ & 2.00 & 0.001 & $89.5^{\mathrm{B}}$ & $83.1^{\mathrm{A}}$ & 1.18 & 0.001 \\
\hline Cys & $76.0^{\mathrm{B}}$ & $65.8^{A}$ & 1.79 & 0.001 & $80.0^{\mathrm{B}}$ & $74.3^{\mathrm{A}}$ & 1.02 & 0.001 \\
\hline Thr & $78.3^{\mathrm{B}}$ & $73.3^{\mathrm{A}}$ & 1.00 & 0.01 & 82.9 & 81.8 & 0.48 & NS \\
\hline Trp & $71.4^{\mathrm{B}}$ & $59.3^{\mathrm{A}}$ & 1.97 & 0.001 & 64.9 & 65.3 & 1.30 & NS \\
\hline Ile & $78.5^{\mathrm{B}}$ & $73.7^{\mathrm{A}}$ & 0.95 & 0.01 & $80.5^{\mathrm{b}}$ & $77.6^{\mathrm{a}}$ & 0.69 & 0.05 \\
\hline His & $84.3^{\mathrm{B}}$ & $77.5^{\mathrm{A}}$ & 1.08 & 0.001 & $84.5^{\mathrm{B}}$ & $81.4^{\mathrm{A}}$ & 1.04 & 0.01 \\
\hline Leu & $75.6^{\mathrm{B}}$ & $71.2^{\mathrm{A}}$ & 0.90 & 0.01 & 82.4 & 80.6 & 0.58 & NS \\
\hline Phe & $81.5^{\mathrm{B}}$ & $74.2^{\mathrm{A}}$ & 1.26 & 0.001 & $84.6^{\mathrm{b}}$ & $82.4^{\mathrm{a}}$ & 0.57 & 0.05 \\
\hline Val & $77.6^{\mathbf{B}}$ & $71.4^{\mathrm{A}}$ & 1.06 & 0.001 & $82.1^{\mathrm{b}}$ & $79.4^{\mathrm{a}}$ & 0.66 & 0.05 \\
\hline
\end{tabular}

${ }^{1}$ calculated as standardized for pigs

${ }^{2}$ Agra, Grapis - low- and high-tannin pea cultivars containing 0.4 and $5.2 \mathrm{~g}$ tannin per $\mathrm{kg}$ of DM, respectively

$\mathrm{a,b}$ - means in the same row with different superscripts differ at $\mathrm{P} \leq 0.05$

$\mathrm{A}, \mathrm{B}$ - means in the same row with different superscripts differ at $\mathrm{P} \leq 0.01$

$\mathbf{A}, \mathbf{B}$ - means in the same row with different superscripts differ at $\mathrm{P} \leq 0.001$

True ileal digestibility of AA was also higher in rats fed the diet with the pea var. Agra than with var. Grapis (Table 5), however, the values were significantly different only for methionine, cystine, isoleucine, histidine, phenylalanine and valine. Of the non essential amino acids, the highest differences in digestibility ( 86 vs $72 \%$ ) was found for proline. The smaller response of rats than pigs to tannins may be related to the secretion of proline-rich protein by the parotid glands in rats (Jansman et al., 1994). It was found that the proline-rich proteins form complexes with tannins and the tannins can not interact with feed proteins or other endogenous proteins such as digestive enzymes. 
Protein SID determined in vitro was highest for the pea Albatros and lowest for peas Retro and Almara (Table 6), after exclusion of var. Grapis which was the lowest in spite of relatively low tannin content.

TABLE 6 In vitro standardized ileal digestibility of protein and amino acids of six varieties of pea containing different levels of tannins, $\mathrm{g} \mathrm{kg}^{-1} \mathrm{DM}$

\begin{tabular}{|c|c|c|c|c|c|c|}
\hline \multirow{2}{*}{$\begin{array}{l}\text { Pea } \\
\text { cv. }\end{array}$} & \multicolumn{2}{|c|}{ Low-tannin } & \multicolumn{4}{|c|}{ High-tannin } \\
\hline & Albatros & Agra & Grapis & Selga & Retro & Almara \\
\hline Tannins & 0.20 & 0.40 & 5.20 & 8.20 & 9.50 & 11.5 \\
\hline Protein & 95.9 & 86.3 & 82.6 & 87.3 & 85.0 & 85.6 \\
\hline Lys & 94.8 & 90.2 & 87.0 & 86.0 & 83.5 & 84.1 \\
\hline Met & 91.6 & 88.3 & 84.0 & 82.0 & 79.9 & 80.5 \\
\hline Cys & 90.6 & 84.7 & 81.1 & 82.2 & 80.0 & 80.2 \\
\hline Thr & 91.4 & 85.2 & 81.7 & 81.6 & 78.9 & 79.2 \\
\hline Ile & 93.9 & 88.3 & 83.8 & 85.0 & 82.4 & 83.0 \\
\hline His & 93.9 & 89.3 & 84.7 & 84.9 & 82.3 & 82.9 \\
\hline Leu & 94.2 & 88.4 & 85.0 & 83.9 & 82.5 & 83.2 \\
\hline Phe & 93.8 & 88.5 & 84.0 & 85.0 & 82.2 & 83.0 \\
\hline Val & 93.3 & 87.0 & 83.2 & 83.9 & 81.5 & 82.2 \\
\hline
\end{tabular}

The values of SID of protein and AA determined by the in vitro method were higher than the corresponding values determined in vivo for the peas Agra and Grapis. Standardized ileal digestibility of AA determined in vitro in six varieties of pea decreased linearly with increasing tannin content (Table 7). The highest correlation was obtained for methionine, lysine, and histidine, a lowest one for phenylalanine, valine, and cystine. It was not significant for protein what is not consistent with results of Garrido et al. (1991) who found a close $(r=-0.88)$ relationship between the tannin content and in vitro protein digestibility in faba bean seeds.

TABLE 7

Relationship between tannin contents (X) and standardized ileal digestibility of protein and amino acids determined in vitro $(\mathrm{Y})$

\begin{tabular}{lccl}
\hline Indices & Equation: $\mathrm{Y}=\mathrm{b}+\mathrm{a} X$ & $\mathrm{r}$ & $\mathrm{P} \leq$ \\
\hline Protein & $\mathrm{Y}=90.1-5.13 \mathrm{X}$ & -0.532 & $\mathrm{NS}$ \\
Lys & $\mathrm{Y}=92.4-8.23 \mathrm{X}$ & -0.920 & 0.01 \\
Met & $\mathrm{Y}=89.9-9.39 \mathrm{X}$ & -0.957 & 0.01 \\
Cys & $\mathrm{Y}=87.3-7.08 \mathrm{X}$ & -0.831 & 0.05 \\
Thr & $\mathrm{Y}=88.1-8.72 \mathrm{X}$ & -0.880 & 0.05 \\
Ile & $\mathrm{Y}=90.6-7.84 \mathrm{X}$ & -0.851 & 0.05 \\
& & & \\
His & $\mathrm{Y}=91.3-8.45 \mathrm{X}$ & -0.903 & 0.05 \\
Leu & $\mathrm{Y}=90.9-8.14 \mathrm{X}$ & -0.879 & 0.05 \\
Phe & $\mathrm{Y}=90.7-7.95 \mathrm{X}$ & -0.865 & 0.05 \\
Val & $\mathrm{Y}=89.7-7.81 \mathrm{X}$ & -0.840 & 0.05 \\
\hline
\end{tabular}




\section{Effect of trypsin inhibitor activity on protein and AA digestibility in soyabean feeds}

Raw soyabean and ESB contained less crude protein $\left(386.9\right.$ and $361.5 \mathrm{~g} \mathrm{~kg}^{-1}$ $\mathrm{DM}$, respectively) as compared with SBM $\left(518.9 \mathrm{~g} \mathrm{~kg}^{-1} \mathrm{DM}\right)$ due to the higher fat content of RSB and ESB (220 and $240 \mathrm{~g} \mathrm{~kg}^{-1} \mathrm{DM}$ ). Trypsin inhibitor activity, expressed in mg inhibited trypsin per g of DM, was 3.8, 32.6 and 15.5 for SBM, RSB and ESB, respectively (Table 3 ). Heating raw soyabean can reduce TIA by $57-90 \%$, sometimes to the level that occurs in SBM (Herkelman et al., 1992). Inclusion of RSB or ESB in the diets increased TIA from 0.90 (in the control diet containing solely SBM) to 3.94 and 2.23 units, respectively.

Inclusion of RSB in the diet significantly decreased $(\mathrm{P} \leq 0.001) \mathrm{SID}$ of protein and AA in pigs (Table 8). Similarly, TID of protein and AA of the diet with RSB was lower in rats, as compared with the SBM diet (P $\leq 0.001$; Table 9). Inclusion of ESB in the diet for rats also decreased TID of protein and AA, however, the values were significantly different only for lysine, tryptophan, histidine, leucine, phenylalanine and valine $(\mathrm{P} \leq 0.001)$. Protein digestibility in rats was low as compared to essential AA digestibility in rats and protein digestibility in pigs (Tables 8 and 9).

The negative effect of trypsin inhibitor on protein and AA digestibility is related to the formation of complexes between trypsin inhibitor and trypsin, what decreases trypsin activity and increases protein losses. Protein and AA digestibility of differently processed soya products may be also related to changes in protein structure and damage of AA during heating.

TABLE 8

Standardized ileal protein and amino acid digestibility of soyabean products determined in pigs and in vitro

\begin{tabular}{|c|c|c|c|c|c|c|c|}
\hline \multirow{3}{*}{ Indices } & \multicolumn{4}{|c|}{ Pigs } & \multicolumn{3}{|c|}{ In vitro } \\
\hline & \multirow{2}{*}{$\begin{array}{c}\text { soyabean } \\
\text { meal }\end{array}$} & \multirow{2}{*}{$\begin{array}{c}\text { soyabean meal } \\
+ \text { raw soyabean }\end{array}$} & \multirow[b]{2}{*}{ SEM } & \multirow[b]{2}{*}{$\mathrm{P} \leq$} & \multirow{2}{*}{$\begin{array}{c}\text { soyabean } \\
\text { meal }\end{array}$} & \multicolumn{2}{|c|}{ Soyabean meal } \\
\hline & & & & & & $\begin{array}{c}+ \text { raw } \\
\text { soyabean }\end{array}$ & $\begin{array}{l}+ \text { extruded } \\
\text { soyabean }\end{array}$ \\
\hline Protein & $84.5^{\mathrm{B}}$ & $61.9^{\mathrm{A}}$ & 3.48 & 0.001 & 90.4 & 93.5 & 94.4 \\
\hline Lys & $89.9^{\mathrm{B}}$ & $72.7^{\mathrm{A}}$ & 2.65 & 0.001 & 91.7 & 93.9 & 94.6 \\
\hline Met & $91.0^{\mathrm{B}}$ & $79.1^{\mathrm{A}}$ & 1.91 & 0.001 & 92.6 & 95.4 & 96.2 \\
\hline Cys & $82.8^{\mathrm{B}}$ & $67.6^{\mathrm{A}}$ & 2.47 & 0.001 & 88.4 & 90.6 & 91.3 \\
\hline Thr & $86.7^{\mathrm{B}}$ & $62.4^{\mathrm{A}}$ & 3.77 & 0.001 & 89.8 & 92.0 & 92.6 \\
\hline Trp & $91.7^{\mathrm{B}}$ & $62.5^{\mathrm{A}}$ & 4.48 & 0.001 & & & \\
\hline Ile & $88.6^{\mathrm{B}}$ & $64.3^{\mathrm{A}}$ & 3.70 & 0.001 & 90.9 & 94.0 & 94.9 \\
\hline His & $90.1^{\mathrm{B}}$ & $72.6^{\mathrm{A}}$ & 2.68 & 0.001 & 81.8 & 95.1 & 96.0 \\
\hline Leu & $86.7^{\mathrm{B}}$ & $60.3^{\mathrm{A}}$ & 4.03 & 0.001 & 90.9 & 92.5 & 93.2 \\
\hline Phe & $89.3^{\text {B }}$ & $66.5^{\mathrm{A}}$ & 3.47 & 0.001 & 91.2 & 94.2 & 95.1 \\
\hline Val & $87.3^{\mathrm{B}}$ & $63.1^{\mathrm{A}}$ & 3.70 & 0.001 & 89.9 & 92.4 & 93.1 \\
\hline
\end{tabular}

$\mathrm{A}, \mathrm{B}-$ means in the same row with different superscripts differ at $\mathrm{P} \leq 0.001$ 
TABLE 9

True ileal protein and amino acid digestibility of soyabean products determined in rats

\begin{tabular}{|c|c|c|c|c|c|}
\hline \multirow[b]{2}{*}{ Indices } & \multirow{2}{*}{$\begin{array}{c}\text { Soyabean } \\
\text { meal }\end{array}$} & \multicolumn{2}{|c|}{ Soyabean meal } & \multirow[b]{2}{*}{ SEM } & \multirow[b]{2}{*}{$\mathrm{P} \leq$} \\
\hline & & $\begin{array}{c}+ \text { raw } \\
\text { soyabean }\end{array}$ & $\begin{array}{c}+ \text { extruded } \\
\text { soyabean }\end{array}$ & & \\
\hline Protein & $76.4^{\mathrm{B}}$ & $64.0^{\mathrm{A}}$ & $76.2^{\mathrm{B}}$ & 1.61 & 0.001 \\
\hline Lys & $86.8^{C}$ & $72.2^{\mathrm{A}}$ & $83.9^{\mathrm{B}}$ & 1.73 & 0.001 \\
\hline Met & $89.9^{\mathrm{B}}$ & $73.2^{\mathrm{A}}$ & $90.0^{\mathrm{B}}$ & 2.13 & 0.001 \\
\hline Cys & $79.3^{\mathrm{B}}$ & $54.1^{\mathrm{A}}$ & $77.4^{\mathrm{B}}$ & 3.13 & 0.001 \\
\hline Thr & $80.6^{\mathrm{B}}$ & $61.9^{\mathrm{A}}$ & $77.9^{\mathrm{B}}$ & 2.27 & 0.001 \\
\hline $\operatorname{Trp}$ & $77.1^{\mathrm{C}}$ & $42.5^{\mathrm{A}}$ & $68.3^{\mathrm{B}}$ & 3.98 & 0.001 \\
\hline Ile & $82.3^{\mathrm{B}}$ & $63.1^{\mathrm{A}}$ & $80.3^{\mathrm{B}}$ & 2.35 & 0.001 \\
\hline His & $84.6^{\mathrm{C}}$ & $68.2^{\mathrm{A}}$ & $82.1^{\mathrm{B}}$ & 1.99 & 0.001 \\
\hline Leu & $83.9^{\mathrm{C}}$ & $66.4^{\mathrm{A}}$ & $80.2^{\mathrm{B}}$ & 2.07 & 0.001 \\
\hline Phe & $84.3^{\mathrm{C}}$ & $68.7^{\mathrm{A}}$ & $80.6^{\mathrm{B}}$ & 1.83 & 0.001 \\
\hline Val & $83.3^{\mathrm{C}}$ & $63.7^{\mathrm{A}}$ & $78.6^{\mathrm{B}}$ & 2.30 & 0.001 \\
\hline
\end{tabular}

A, B, C - means in the same row with different superscripts differ at $\mathrm{P} \leq 0.001$

In contrast with in vivo results, SID of protein and AA determined in vitro was not negatively affected by inclusion of RSB or ESB in digested soyabean mixtures (Table 8). It can be suggested that soya TIA did not influence the digestion process. This result was probably due to the excess of enzyme used for digestion in vitro. These results are in agreement with data obtained by Clemente et al. (2000), who found no influence of TIA on in vitro protein digestibility in pea. Different results were obtained by Capetillo et al. (2001), who found significantly $(\mathrm{P} \leq 0.05)$ lower in vitro protein digestibility of raw soyabean as compared with soyabean meal (52.3 and 86.9\%, respectively) and Martinez et al. (1998) who found a negative relationship $(\mathrm{r}=-0.65, \mathrm{P} \leq 0.05)$ between trypsin inhibitor activity and protein digestibility determined in vitro in green beans.

\section{CONCLUSIONS}

The feasibility of alternative methods for prediction of AA SID for pigs depends on type of feeds and factors impairing digestion. In vitro method is a useful way of ranking pea cultivars for pig feeding while digestibility in rats gives a useful model to rank soyabean products for pigs. 


\section{REFERENCES}

An J., Bacon J.R., Fenwick G.R., 1993. Standarization of the extraction procedure for the analysis of trypsin inhibitors in pea seeds. In: A.F.B. van der Poel, J. Huisman, H.S. Saini (Editors). Recent Advances of Research in Antinutritional Factors in Legume Seeds. Wageningen Pers, (The Netherlands), pp. 31-35

AOAC, 1990. Official Methods of Analysis, Association of Official Analytical Chemists. $15^{\text {th }}$ Edition. Washington, DC

Boisen S., 1998. A new protein evaluation system for pig feeds and its practical application. Acta Agr. Scand., Sect. A, Anim. Sci. 48, 1-11

Boisen S., Fernández J.A., 1995. Prediction of the apparent ileal digestibility of protein and amino acids in feedstuffs and feed mixtures for pigs by in vitro analyses. Anim. Feed Sci. Tech. 51, $29-43$

Boisen S., Moughan P.J., 1996. Dietary influence on endogenous ileal protein and amino acid loss in the pigs - a review. Acta Agr. Scand., Sect. A, Anim. Sci. 46, 154-164

Buraczewska L., Buraczewski S., 1984. A note on determination of methionine and tryptophan. Proceedings of $6^{\text {th }}$ International Symposium Amino Acids, Serock (Poland). Polish Scientific Publishers, Warszawa, pp. 47-50

Capetillo C.M., Abreu J.E., Belmar R., 2001. Standarization of an in vitro method for predicting N digestibility in pig diets. Cuban J. Agr. Sci. 35, 349-353

Clemente A., Vioque J., Sánchez-Vioque R., Pedroche J., Bautista J., Millán F., 2000. Factors affecting the in vitro protein digestibility of chickpea albumins. J. Sci. Food Agr. 80, 79-84

Donkoh A., Moughan P.J., Morel P.C.H., 1995. Comparison of methods to determine the endogenous amino acid flow at the terminal ileum of the growing rats. J. Sci. Food Agr. 67, 359-366

Garrido A., Gómez-Cabrera A., Guerrerro J.A.E., Marquard R.R., 1991. Chemical composition and digestibility in vitro of Vicia faba L. cultivars varying in tannin content. Anim. Feed Sci. Tech. $35,205-211$

Gdala J., Buraczewska L., Grala W., 1992. The chemical composition of different types and varieties of pea and the digestion of their protein in pigs. J. Anim. Feed Sci. 1, 71-79

Grosjean F., Jondreville C., Williatte-Hazouard I., Skiba F., Carroueé B., Gatel F., 2000. Ileal digestibility of protein and amino acids of feed peas with different trypsin inhibitor activity in pigs. Can. J. Anim. Sci. 80, 643-652

Hendriks W.H., Sritharan K., Hodgkinson S.M., 2002. Comparison of the endogenous ileal and faecal amino acid excretion in the dog (Canis familiaris) and the rat (Rattus rattus) determined under protein-free feeding and peptide alimentation. J. Anim. Physiol. Anim. Nutr. 86, 333-341

Herkelman K.L., Cromwell G.L., Stahly T.S., Pfeiffer T.W., Knabe D., 1992. Apparent digestibility of amino acids in raw and heated conventional and low-trypsin-inhibitor soybeans for pigs. J.Anim. Sci. 70, 818-826

Jansman A.J.M., Frohlich A.A., Marquardt R.R., 1994. Production of prolin-rich proteins by the parotid glands of rats is enhanced by feeding diets containing tannins from faba beans (Vicia faba L.). J. Nutr. 124, 249-258

Kakade M.L., Rackis J.J., McGhee J.E., Puski G., 1974. Determination of trypsin inhibitor activity of soy products: A collaborative analysis of an improved procedure. Cereal Chem. 51, 376-382

Kimura F.T., Miller V.L., 1957. Improved determination of chromic oxide in cow feed and feces. J. Agr. Food Chem. 5, 216

Kuhla S., Ebmeier C., 1981. Untersuchungen zum Tanningehalt in Ackerbohnen. 1. Mitt.: Methodishe Untersuchungen zur Bestimmung der Kondensierten Tannine in Ackerbohnen. Arch. Tierenähr. 31, 573-588 
Martinez C., Ros G., Periago M.J., Ortuňo J., López G., Rincón F., 1998. In vitro protein digestibility and mineral availability of green beans (Phasolus vulgaris L.) as influenced by variety and pod size. J. Sci. Food Agr. 77, 414-420

Mosenthin R., Sauer W.C., Blank R., Huisman J., Fan M.Z., 2000. The concept of digestible amino acids in diet formulation for pigs. Livest. Prod. Sci. 64, 265-280

Rademacher M., Sauer W.C., Jansman A.J.M., 1999. Standardized Ileal Digestibility of Amino Acids in Pigs. Degussa-Hülls AG Publication, Frankfurt (Germany)

Rutherfund S.M., Moughan P.J., 2003. The rat as a model animal for the growing pig in determining ileal amino acid digestibility in soya and milk protein. J. Anim Physiol. Anim. Nutr. 87, 292-300

Skilton G.A., Smith W.C., Moughan P.J., 1991. The ileal digestibility of nitrogen and amino acids in meat and bone meals determined using a rat assay. Anim. Feed Sci. Tech. 34, 111-126

StatSoft Inc., 1997. Statistica 5.5 PL for Windows, Tulsa (USA)

Valdebouze P., Berderon E., Gaboit T., Delerot-Laval J., 1980. Content and distribution of trypsin inhibitors and hemagglutinins in some legume seeds. Can. J. Plant Sci. 60, 695-701

Van Leeuwen P., van Kleef D., van Kempen G.J.M., Huisman J., Verstegen M.W.A., 1991. The post valve T-caecum cannulation technique in pigs applicated to determine the digestibility of amino acid in maize, groundnut and sunflower meal. J. Anim. Physiol. Anim. Nutr. 65, 183-193

Van Soest P.J., 1973. Collaborative study of acid detergent fiber and lignin. J. Assn. Off. Anal. Chem. 56, 513-530

Van Soest P.J., Wine R.H., 1967. Use of detergents in the analysis of fibrous feeds. IV. Determination of plant cell wall constituents. J. Assn. Off. Anal. Chem. 50, 50-55

Van Wijk H.J., Moughan P.J., Hodgkinson S.M., Jensen P.P., Pearson G., 1998. Variation in apparent and true ileal amino acid digestibility in barley using a rat model. Anim. Feed Sci. Tech. 76, 9-22

\section{STRESZCZENIE}

\section{Rzeczywista strawność jelitowa aminokwasów nasion grochu i produktów sojowych oznaczona na świniach, szczurach oraz in vitro}

Standaryzowaną/rzeczywistą strawność jelitową białka i aminokwasów (AA) niskoi wysokotaninowych nasion grochu oraz pasz sojowych (śruta sojowa, surowa soja lub soja ekstrudowana) o różnej aktywności inhibitora trypsyny oznaczono i porównano u rosnących świń i dorosłych szczurów oraz metodą in vitro. Ilość białka i AA pochodzenia endogennego w treści końcowego odcinka jelita cienkiego u szczurów żywionych dietą bezbiałkowa była zbliżona do średnich wartości tabelarycznych dla świń. U świń standaryzowana strawność jelitowa białka i AA grochu niskotaninowego była istotnie większa $(\mathrm{P} \leq 0.05)$ niż grochu wysokotaninowego. U szczurów różnice w strawności rzeczywistej porównywanych grochów uzyskano tylko dla kilkuAA(metionina, cystyna, izoleucyna, histydyna, fenyloalanina, walina). Oznaczona in vitro standaryzowana strawność jelitowa sześciu odmian grochu zmniejszała się wraz ze wzrostem zawartości tanin w nasionach. Strawność jelitowa AA pasz sojowych u obydwóch gatunków zwierząt zależała od aktywności inhibitora trypsyny, która nie miała wpływu na strawność oznaczoną in vitro. Wnioskuje się, że alternatywne metody mogą być stosowane do oceny strawności jelitowej aminokwasów pasz dla świń, jednakże do oceny pasz sojowych zawierających czynnik antytrypsynowy właściwsze jest użycie szczurów, podczas gdy metoda in vitro pozwala na lepsze oszacowanie dostępności AA z pasz zawierających taniny. 